\title{
Mining of rich iron ore deposits of complex structure under the conditions of rock pressure development
}

\author{
Serhii Pysmennyi ${ }^{1 *}$, Mykhailo Fedko ${ }^{1}$, Nataliia Shvaher $^{2}$, and Serhii Chukharev ${ }^{3}$ \\ ${ }^{1}$ Kryvyi Rih National University, Department of Underground Mining of Mineral Deposit, \\ 11 Matusevycha St., 50027 Kryvyi Rih, Ukraine \\ ${ }^{2}$ Kryvyi Rih National University, Department of labor protection and civil security, 11 Matusevycha \\ St., 50027 Kryvyi Rih, Ukraine \\ ${ }^{3}$ National University of Water and Environmental Engineering, Department of Development of \\ Deposits and Mining, 11 Soborna St., 33028 Rivne, Ukraine
}

\begin{abstract}
The purpose of research is to increase the ore mass extraction ratio when mining rich iron ores by changing the shape of the stope chamber, as well as to substantiate its stable parameters under the conditions of the rock pressure manifestation. Used in mines existing methodologies for determining the structural elements of mining system are based on calculated equivalent spans of outcropping the stope chambers, which have a rectangular or tent shape. For the first time using the ANSYS software package, it has been determined that the formation of a compensation chamber of quasi-parabolic shape can significantly reduce the stresses concentration around the stope block. Thus, the formation of a stope chamber of a quasi-parabolic shape makes it possible to reduce vertical stresses as compared to horizontal ones without increasing horizontal pressure. When mining the extraction block, it is proposed to form the stope chamber of a quasi-parabolic shape with geometric parameters that directly depend on the parameters of the deposit, the depth of mining, and the direction of main stresses action. Dependences have been determined of the stresses value on the depth of mining and the physical properties of rocks, as well as on the length along the strike of the ore deposit. Thus, depending on the mining depth and length along the strike, rock pressure on the stope chamber of a quasi-parabolic shape decreases under non-uniform loading. The formation of a stope chamber of a quasi-parabolic shape will increase by $1.2-1.5$ times the volume of pure ore that is recovered from the block.
\end{abstract}

\section{Introduction}

Iron ores of the Kryvyi Rih Iron-ore Basin are mined by underground method at a depth below $1350 \mathrm{~m}$ with a useful component content of $58-67 \%$ in the massif [1-3]. When using traditional systems of mining, the iron content in the mined ore mass does not exceed $59-61 \%$. A decrease in the iron content in the mined ore mass leads to losses in the global

\footnotetext{
*Corresponding author: psvknu@gmail.com
} 
market, and this is caused by the fact that the market needs products with a higher iron content than $62 \%$ in marketable products [ $4-6]$.

In order to be in demand in the global market, mining enterprises increase the efficiency of mining the deposits by improving certain technological processes, namely: application of various methods for minerals beneficiation in underground or above-ground conditions [7-11], the improvement of mining systems used in mines [12-18], and introduce the latest technological elements of the mining system at the first stage of underground mining of the stope block, which ensure the extraction of not diluted ore at the level of $88-92 \%$ [19-22]. It should be noted that the proposed technological processes can significantly increase the iron content in the mined ore mass, however, production costs may increase by $1.2-1.4$ times.

In the Kryvyi Rih Iron-ore Basin, when using traditional mining systems at an increased depth of mining, high and low pressure zones simultaneously arise around the mined-out space. This leads to formation of rock falls [23-25], and, as a consequence, to additional ore dilution before mining the stope block (at the stage of the compensation space formation).

The authors in the works [ $26-31]$ propose to improve the process of the mined ore mass beneficiation by automating the process and taking into account the physical-chemical properties of minerals. This significantly increases the useful component content in the mined ore mass, however, the cost price of marketable products increases, production volumes decrease, and the ecological situation in the region worsens, which requires certain costs for its remediation $[32,33]$. Therefore, it is expedient to reduce the ore dilution directly in the block.

In the works [34 - 42], the authors improve the ore mining technology by optimizing certain technological processes. This significantly reduces the production costs and improves working conditions during underground mining operations. The performed laboratory studies confirm the effectiveness of the certain processes modernization [43 - 48]. Thus, with the improvement of a certain technological process, the useful component content in the mined ore mass increases by $1.0-1.5 \%$.

It should be noted that the ore deposits of the Kryvyi Rih Iron-ore Basin are heterogeneous and have a complex structure. The development of such deposits by traditional systems of mining leads to worsening the extraction ratio due to waste rock inclusions in the ore massif. The authors of the works [49-54] propose various mining systems, which are based on the selective mining of iron ore. This technology includes the stage-by-stage mining of the stope block and the separation of ore from waste rock directly in underground conditions.

This principle of mining is widely used at the Kiruna mine (Sweden), where an iron ore deposit is developed. In order to improve the useful component quality of the mined ore mass in the final product, it is sorted at the stage of transportation in underground conditions [55 - 57]. This enables output of the final product with a useful component of appropriate quality without beneficiation process, in addition, the extraction ratio of pure ore is $90-92 \%$. The application in the conditions of Kryvyi Rih Iron-ore Basin of mining technology which is used at the Kiruna mine will lead to an increase in operating expenses by $2-5$ times.

The operational experience of mines in the Kryvyi Rih Iron-ore Basin has proved that the efficiency of deposits mining is influenced by the order of stope extraction and the system of mining [58-60]. Thus, when applying a system of mining with end drawing of ore, the authors of the works $[61-64]$ make a conclusion that when the seams from the side of the hanging wall are mined in advance, this reduces the rock pressure in the ore body along the main strike. In order to increase the useful component content in the mined ore mass, the selective mining of rich ores by systems with mass collapse and with an open stope space is proposed. The proposed technological solutions can significantly increase the useful component content in the mined ore mass by $2-5 \%$ without increasing the production costs and additional beneficiation processes. However, when using these mining systems in unstable rocks, waste rocks penetrate into the compensation space at the stage of preparing 
the stope block for extraction, which significantly worsens the extraction ratio $[1-3]$.

As a result of research $[1,20]$, it has been revealed that the shape of the compensation space greatly influences on the rock massif stability in the conditions of the rock pressure manifestation. Thus, it has been proved that when mining the deposit of the main strike using a sloping compensation chamber, the normal stresses in the upper part of outcropping span decrease by 4 times. And the most unstable shape of the chamber is horizontal, due to an increase in normal stresses at significant depths by 2 times compared with vertical or sloping compensation chambers.

According to the practice data and theoretical studies, mine workings of a round, tent and arched shapes are the most stable forms of the mined space. When mining steeply dipping stratified ore deposits, it is practically impossible to mine an extraction block using round or tent-shaped stope chambers. This is explained by the geological conditions of the Kryvyi Rih Iron-ore Basin. If to construct an arch-shaped stope chamber with a height of $45-90 \mathrm{~m}$ under the conditions of the Kryvyi Rih Iron-ore Basin, it leads to ore losses up to $20-25 \%$ during mining the pillars between chambers. When decreasing the ore losses to the normative $16 \%$, the pure ore extraction ratio does not exceed $70 \%$.

\section{Methods}

To solve the problem of increasing the iron content and reducing ore losses during mining of ore deposits with a complex structure, it is advisable to apply the approach proposed in the works $[1-3]$. The authors propose to modernize the traditional beneficiation processes by involving the techniques of hydrometallurgical and chemical processing, which increase the beneficiation efficiency through the use of other energy types. This direction of beneficiation modernization is based on the processes of force action on a substance during disintegration in the activator and is not related to the processes of underground mining of minerals.

Based on the performed critical analysis of the works devoted to mining and processing of minerals, the following conclusions can be drawn:

1. With the purpose of increasing the iron content in the mined ore mass, the authors propose underground or above-ground beneficiation of the mined ore mass, which will lead to an increase in the production costs of marketable products.

2. Increasing the iron content in the mined ore mass by changing the order of mining the blocks and the mining system (chamber systems of mining with a temporary pillar, which is remained between them). However, under the conditions of the rock pressure development, further mining of pillars between the chambers will lead to worsening the extraction ratio of their mining or to the impossibility of their mining.

Thus, there is a need to improve the technology of rich iron ore mining, which could increase the iron content in the mined ore mass under conditions of the rock pressure manifestation at great depths.

\section{Results and discussion}

The efficiency of mining system is determined by the extraction ratio and the ore mass production costs. To increase the mining system efficiency, it is expedient to increase the volume of the stope chamber while providing it with stable parameters. An increase in the volume of a rectangular-shaped stope chamber by $1.1-1.5$ times leads to a decrease in its stability and an increase in the pillars width, the time of mining the block (panel), operating expenses, and the expenditures for mining the pillars between chambers.

According to the studies $[1-3]$, a shape of the stope chamber should be close to the figure of drawing, which is an ellipse. It should be noted at the same time that the conditions of the chamber stability are not determined. In the work [60], the author states that when 
constructing parabolic-shaped stope chambers, the chamber stability and its volume increases (Fig. 1).

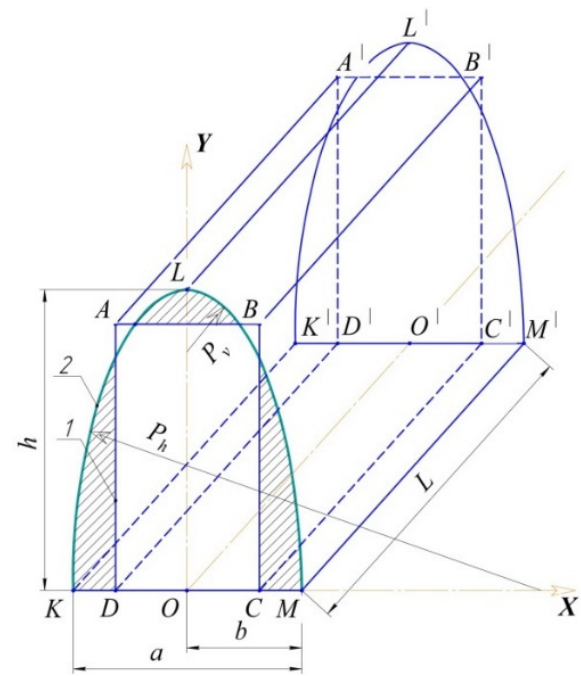

Fig. 1. Computational scheme for determining the volume of a parabolic-shaped chamber: 1 - contour of a rectangular-shaped chamber; 2 - contour of a parabolic-shaped chamber.

The points coordinates of the $K L M$ curve, which describes a parabolic-shaped chamber (Fig. 1), are determined by the expression:

$$
y=-c \cdot \frac{\int\left(x^{2 \cdot k-1} d x\right)}{\sqrt{\left(b^{2}-x^{2}\right)^{r}}} \text { at } k>0,5 ; 0<r<2,
$$

where c, $k$ are real numbers; $r$ is smaller odd real number; $x, y$ are current coordinates.

When changing the values of $x$ from 0 to $b$, the function curve decreases, and the curve $M L$ is convex for all values of the derivative $-b<x<b$. The stope chamber stability is ensured in the case when the current maximum stresses in the mine rock massif are less than the ultimate strength of the ore or the rocks surrounding it. The condition of stable equilibrium is described by the expressions $[61], \mathrm{t} / \mathrm{m}^{2}$ :

$$
\sigma_{\max } \leq[\sigma], \quad \tau_{\max } \leq[\tau], \quad \sigma>>,
$$

where $\sigma_{\max }$ is maximum stresses of internal forces in the massif, $\mathrm{t} / \mathrm{m}^{2} ; \tau$ is maximum shearing stresses occurring in the massif, $\mathrm{t} / \mathrm{m}^{2} ;[\sigma]$ is ultimate strength of the material, $\mathrm{t} / \mathrm{m}^{2}$.

It is known that when calculating the pillars stability, the main criterion is bending $[66,67]$. However, in the rocks of massif when exceeding the maximum stresses, the zones of fractures are formed, which lead to a decrease in the ultimate strength of the pillar composed by rocks, and eventually to its destruction.

In the work [65], it is proved that the specific weight and depth of mining influence on the main vertical stresses. In the virgin rock massif, the main vertical stresses are maximum, and during underground mining operations they remain unchanged or decrease. Thus, the value of the critical pressure must satisfy the boundary conditions $[65,68], \mathrm{t} / \mathrm{m}^{2}$ :

$$
\left\{\begin{array}{l}
{[\sigma] \geq \sigma_{3} ;} \\
\sigma_{3}=\gamma \cdot H,
\end{array}\right.
$$


where $\sigma_{3}$ is main vertical stresses, $\mathrm{t} / \mathrm{m}^{2} ; \gamma$ is specific weight of mine rocks, $\mathrm{t} / \mathrm{m}^{3} ; H$ is depth of mining operations, $\mathrm{m}$.

According to the studies $[68,69]$, it has been proved that the critical pressure arising on the contour of the chamber depends on the radius of the curvilinear outcropping of the mine working, the angle of the applied load, and the physical-chemical properties of mine rocks. The volume of the parabolic-shaped chamber is determined from the expression, $\mathrm{m}^{3}$ :

$$
V= \pm 2 \cdot L \cdot a \cdot \int_{0}^{b}\left(2 \cdot \sqrt[3]{\left.\frac{\sigma_{3}^{2}}{\left[\sigma_{s t}\right]}\right)} \cdot \sqrt[4]{\left(1-\frac{x^{2} d x}{4 \cdot \sigma_{3} \cdot \sqrt[3]{\frac{\sigma_{3}^{2} \cdot \cos \beta \cdot \operatorname{tg} \rho}{\left[\sigma_{s t}\right]^{2}}}}\right)^{3}},\right.
$$

where $L$ is length of the stope chamber along the strike, $\mathrm{m} ; a$ is width of a parabolic-shaped stope chamber, $\mathrm{m} ; \beta$ is shear angle of mine rocks, deg.; $\rho$ is angle of internal friction of mine rocks, deg.; $\left[\sigma_{s t}\right]$ is ultimate compressive strength of rocks, $\mathrm{t} / \mathrm{m}^{2}$.

It should be noted that the total pressure $\sigma_{3}$, included into formula (1), is determined as a uniformly distributed load. When determining the load on the stope chamber (extraction block), the weight of the overlying rocks should be taken into account, depending on the order and sequence of mining the block on the level.

The first - the load from the rocks is accepted as uniformly distributed when the height of the dynamic arch is greater than the height of the rocks collapsed to the earth's surface. In this case, the chamber is under impact of the total weight of the overlying rocks, which is determined by the formula, $\mathrm{t} / \mathrm{m}^{2}$ :

$$
\sigma_{3}=\gamma_{b} \cdot H \cdot K_{l},
$$

where $\gamma_{b}$ is specific weight of collapsed rocks, $\mathrm{t} / \mathrm{m}^{3} ; K_{l}$ is coefficient of loosening the overlying rocks in the zone of collapse.

The second - the load is determined by the weight of the rocks enclosed in the arch of unstable equilibrium, when the height of the unstable equilibrium arch is less than the depth of mining, and the condition is satisfied, $\mathrm{m}$

$$
h_{v}<<,
$$

where $h_{v}$ is height of dynamic arch, m.

According to the arch hypothesis [65], the pressure on the block is determined by the weight of the overlying rocks enclosed in the arch of unstable equilibrium or in the dynamically unloaded dome (arch), from which particles move only under their own weight. With a high passing ability of particles and a small angle of internal friction, the displacement occurs very smoothly, and under the impact of vertical forces, the arch collapses, and therefore pulsating shocks are observed.

Velocity of falling out of particles or their replacement in a dynamic arch is determined by the ellipsoid height of the unstable equilibrium, the surface area of the dynamic arch, internal friction between the particles surfaces. The curve of the dynamic arch is described by the equation:

$$
y^{2}=2 \cdot p \cdot x,
$$

where $p$ is height of the arch figure (dynamic arch), $\mathrm{m} ; x$ is current coordinate along the axis $\mathrm{x}-\mathrm{x}$.

The specific load on the chamber from the host rocks, enclosed in an unstable equilibrium arch, is determined by the formula [68], $\mathrm{t} / \mathrm{m}^{2}$ : 


$$
\sigma_{3}=\frac{\pi \cdot L \cdot \gamma_{b}}{8 \cdot f_{r}},
$$

where $f_{r}$ is coefficient of internal friction.

Vertical pressure is always less than horizontal one, but in some mines, pressure can change reversely. Horizontal pressure is determined by the formula [65], $\mathrm{t} / \mathrm{m}^{2}$ :

$$
\sigma_{1,2}=\frac{\mu}{1-\mu} \cdot \sigma_{3}
$$

where $\mu$ is Poison's ratio.

Having performed the calculations according to formulas (2), (3) and (4), the dependences of the stresses value on the depth of mining and the rocks physical properties have been constructed (Fig. 2).

It can be seen from the graphs in Fig. 2 that with a uniformly distributed load, with an increase in the depth of mining from 800 to $1600 \mathrm{~m}$, the pressure increases from 1760 to $3520 \mathrm{t} / \mathrm{m}^{2}$, while the horizontal pressure decreases from 828 to $1656 \mathrm{t} / \mathrm{m}^{2}$. In the case when the pressure does not depend on the weight of the unstable equilibrium arch and on the mining depth, and remains constant, with a length $1000 \mathrm{~m}$ along the strike of the mine field, the pressure is $1727 \mathrm{t} / \mathrm{m}^{2}$.

Fig. 3 presents the dependences of the pressure change in the arch on the length of the ore deposit along the strike.

It can be seen from Fig. 3 that with an increase in the length of mining the ore deposits from 600 to $1400 \mathrm{~m}$, the pressure in the arch increases from 1036 to $2418 \mathrm{t} / \mathrm{m}^{2}$. Thus, it is possible to reduce the pressure in the block by reducing the length of mining the ore deposits, leaving supporting pillars or distributing the deposit into separate extraction blocks.

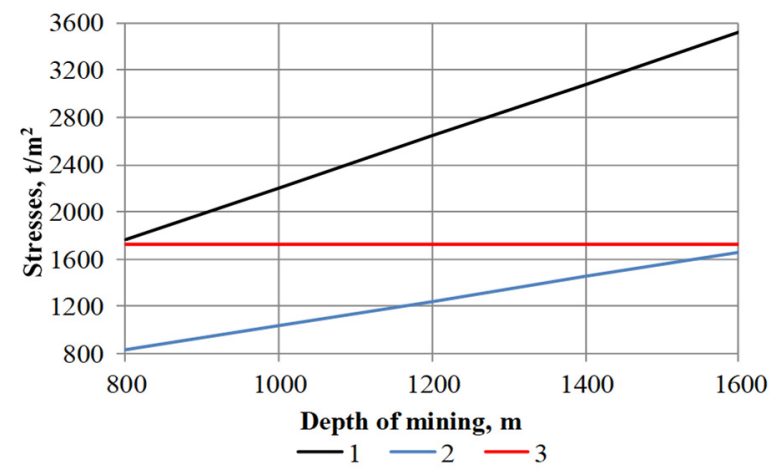

Fig. 2. Dependences of the stresses value on the depth of mining and the rocks physical properties: 1 - uniformly distributed vertical load; 2 - horizontal load; 3 - load in the arch.

In order to confirm theoretical studies, laboratory experiments have been performed by numerical method using finite elements. To do this, using the ANSYS software package, the research has been conducted on the distribution of equivalent stresses around the stope chambers of rectangular and quasi-parabolic shapes (Fig. 4).

It should be taken into account that this software package is able to calculate the equivalent stresses in the massif. Using the ANSYS software package, the stable parameters of the stope chamber structural elements, such as width, length, equivalent stretch of outcropping, have been determined according to the mining-and-geological conditions of the Ternivska mine of PJSC "Kryvbaszalizrudkom". 


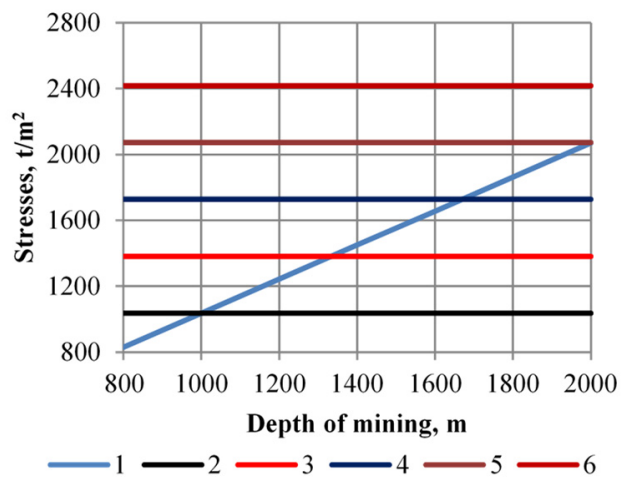

Fig. 3. Dependences of the stresses value on the depth of mining and length along the strike of the ore deposit: 1 - horizontal load; 2, 3, 4, 5 - the load in the arch with a deposit length of $600,800,1000$, 1200 and $1400 \mathrm{~m}$, respectively.

The following data were initial for the calculations: specific weight of the rocks is $2800 \mathrm{~kg} / \mathrm{m}^{3}$; ultimate compressive strength is $60 \mathrm{MPa}$; ultimate tensile strength is $9 \mathrm{MPa}$; Young's modulus is $50000 \mathrm{MPa}$; Poison's ratio is 0.23 ; cross-sectional area of a chamber is $1970 \mathrm{~m}^{2}$; depth of mining is $1200 \mathrm{~m}$. The parameters for the rectangular-shaped stope chamber are as follows: width $-33 \mathrm{~m}$, height $-60 \mathrm{~m}$. For a parabolic-shaped chamber: the radius of the vertical outcropping $-77.5 \mathrm{~m}$, the radius of horizontal outcropping $-5 \mathrm{~m}$, the width of the stope chamber $-50 \mathrm{~m}$ and the height $-60 \mathrm{~m}$.

$a$

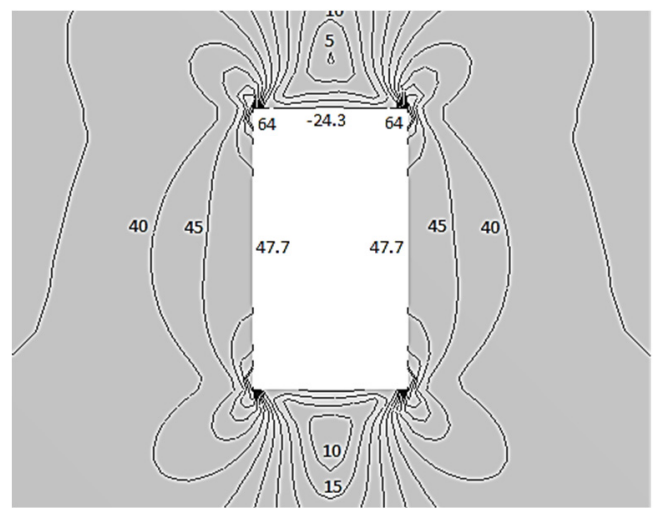

$b$

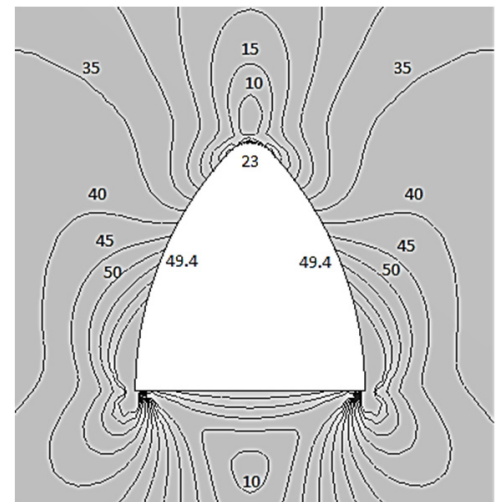

Fig. 4. Distribution of equivalent stresses around the stope chamber: $a$ - rectangular-shaped; $b$ - parabolicshaped.

By analyzing the calculated data (Fig. 4), it has been determined that on the contour of the stope chamber in the middle part compressive stresses act, which differ by no more than $3.45 \%$. It should be noted that the volume of the parabolic-shaped stope chamber is increased by 1.2 times compared to a rectangular-shaped chamber, while the equivalent stresses from the sides of the chamber have the same values.

Thus, it can be argued that a change in the shape of the stope chamber provides it with additional stability by changing the tensile stresses to compressive ones in the upper part of the chamber. 


\section{Conclusions}

It has been determined that in unstable rocks at a depth of $1350 \mathrm{~m}$ and a deposit length along the strike of $600 \mathrm{~m}$, vertical stresses are less than horizontal ones by $370 \mathrm{t} / \mathrm{m}^{2}$. In this case, the stope chamber width increases depending on the ratio of vertical and horizontal outcroppings from 1.08 to 1.55 times, ensuring its stability. With an increase in the length of the deposit along the strike from 600 to $1400 \mathrm{~m}$ with a radius of vertical outcropping of $90 \mathrm{~m}$, the chamber width should be reduced from 1.55 to 1.23 times.

The authors of this paper express their sincere gratitude to the management of the PJSC "Kryvbaszalizrudkom" and the Ministry of Education and Science of Ukraine for their assistance, thanks to which the work has been performed within the framework of state scientific topics "Determination of stress state patterns of rocks disturbed by mining operations with the aim of developing resource-saving technologies for ore mining" (State registration No. 0115U003179).

\section{References}

1. Stupnik, M., Kolosov, V., Pysmennyi, S., \& Kovbyk, K. (2019). Selective mining of complex stuctured ore deposits by open stope systems. E3S Web of Conferences, (123), 01007. https://doi.org/10.1051/e3sconf/201912301007

2. Pysmenniy, S., Shvager, N., Shepel, O., Kovbyk, K., \& Dolgikh, O. (2020). Development of resource-saving technology when mining ore bodies by blocks under rock pressure. E3S Web of Conferences, (166), 02006. https://doi.org/10.1051/e3sconf/202016602006

3. Stupnik, M., Kalinichenko, V., \& Pismennyi, S. (2013). Pillars sizing at magnetite quartzites roomwork. Annual Scientific-Technical Collection - Mining of Mineral Deposits 2013, 11-15. https://doi.org/10.1201/b16354-3

4. Khomenko, O., \& Rudakov, D. (2010). The first Ukrainian corporative university. New Techniques and Technologies in Mining - Proceedings of the School of Underground Mining, 203-206. https://doi.org/10.1201/b11329-34

5. Stupnik, M.I., Kalinichenko, V.O., Kalinichenko, O.V., Muzika, I.O., Fed'ko, M.B., \& Pismennyi, S.V. (2015). The research of strain-stress state of magnetite quartzite deposit massif in the condition of mine "Gigant-Gliboka" of central iron ore enrichment works (CGOK). Metallurgical and Mining industry, (7), 377-383.

6. Stupnik, M., Kalinichenko, V., Fedko, M., Kalinichenko, O., Pukhalskyi, V., \& Kryvokhin, B. (2019). Investigation of the dust formation process when hoisting the uranium ores with a bucket. Mining of Mineral Deposits, 13(3), 96-103. https://doi.org/10.33271/mining13.03.096

7. Morkun, V., Morkun, N., \& Pikilnyak, A. (2014). The adaptive control for intensity of ultrasonic influence on iron ore pulp. Metallurgical and Mining Industry, (6), 8-11.

8. Golik, V., Komashchenko, V., \& Morkun, V. (2015). Feasibility of using the mill tailings for preparation of self-hardening mixtures. Metallurgical and Mining Industry, 7(3), 38-41.

9. Morkun, V., Morkun, N., \& Pikilnyak, A. (2014). Ultrasonic facilities for the ground materials characteristics control. Metallurgical and Mining Industry, (2), 31-35.

10. Morkun, V., Morkun, N., \& Pikilnyak, A. (2015). Adaptive control system of ore beneficiation process based on Kaczmarz projection algorithm. Metallurgical and Mining Industry, (2), 35-38.

11. Morkun, V., \& Tron, V. (2014) Automation of iron ore raw materials beneficiation with the operational recognition of its varieties in process streams. Metallurgical and Mining Industry, (6), 4-7.

12. Kononenko, M., \& Khomenko, O. (2010). Technology of support of workings near to extraction chambers. New Techniques and Technologies in Mining - Proceedings of the School of Underground Mining, 193-197. https://doi.org/10.1201/b11329-32

13. Tarasyutin, V.M. (2015). Geotechnology features of high quality martite ore from deep mines of Kryvyi Rih basin. Naukovyi Visnyk Natsionalnoho Hirnychoho Universytetu, (1), 54-60. 
14. Lutsenko, I., Fomovskaya, E., Koval, S., \& Serdiuk, O. (2017). Development of the method of quasioptimal robust control for periodic operational processes. Eastern-European Journal of Enterprise Technologies, 4(2(88)), 52-60. https://doi.org/10.15587/1729-4061.2017.107542

15. Plevako, V., Potapov,V., Kycenko, V., Lebedynecj I., \& Pedorych, I. (2016). Analytical study of the bending of isotropic plates, inhomogeneous in thickness. Eastern-European Journal of Enterprise Technologies, 4(7(82)), 10-16. https://doi.org/10.15587/1729-4061.2016.75052

16. Stupnik, N., Kalinichenko, V., Kolosov, V., Pismennyy, S., \& Shepel, A. (2014). Modeling of stopes in soft ores during ore mining. Metallurgical and Mining Industry, 6(3), 32-37.

17. Kovalevska, I., Zhuravkov, M., Chervatiuk, V., Husiev, O., \& Snihur, V. (2019). Generalization of trends in the influence of geomechanics factors on the choice of operation modes for the fastening system in the preparatory mine workings. Mining of Mineral Deposits, 13(3), 1-10. https://doi.org/10.33271/mining13.03.001

18. Bondarenko, V., Symanovych, H., Kicki, J., Barabash, M., \& Salieiev, I. (2019). The influence of rigidity of the collapsed roof rocks in the mined-out space on the state of the preparatory mine workings. Mining of Mineral Deposits, 13(2), 27-33. https://doi.org/10.33271/mining13.02.027

19. Kononenko, M., Khomenko, O., Savchenko, M., \& Kovalenko, I. (2019). Method for calculation of drilling-and-blasting operations parameters for emulsion explosives. Mining of Mineral Deposits, 13(3), 22-30. https://doi.org/10.33271/mining13.03.022

20. Stupnik, N., Kalinichenko, V., Pismennij, S. \& Kalinichenko, E. (2015). Features of underlying levels opening at "ArsellorMittal Kryvyic Rih" underground mine. New Developments in Mining Engineering 2015: Theoretical and Practical Solutions of Mineral Resources Mining, 39-44. https://doi.org/10.1201/b19901-8

21. Petlovanyi, M., Lozynskyi, V., Zubko, S., Saik, P., \& Sai, K. (2019). The influence of geology and ore deposit occurrence conditions on dilution indicators of extracted reserves. Rudarsko Geolosko Naftni Zbornik, 34(1), 83-91. https://doi.org/10.17794/rgn.2019.1.8

22. Khomenko, O., Rudakov, D., \& Kononenko, M. (2011). Automation of drill and blast design. Technical And Geoinformational Systems in Mining: School of Underground Mining, 271-275. https://doi.org/10.1201/b11586-45

23. Lavrinenko, V.F., \& Lysak, V.I. (1991). Uroven' udaroopasnosti porod na glubokikh gorizontakh shakht Krivbassa. Razrabotka Rudnykh Mestorozhdeniy, (52), 30-37.

24. Herbert, R., \& Nordström, A. (2017). Leachate generation and nitrogen release from small-scale rock dumps at the Kiruna iron ore mine. In International Mine Water Association Conference (pp. 140-146). Lappeenranta, Finland: Uppsala University Publications.

25. Dolgikh, O., \& Dolgikh, L. (2020). The study of the collapse zone by remote methods. E3S Web of Conferences, (166), 03002. https://doi.org/10.1051/e3sconf/202016603002

26. Morkun, V., Morkun, N., \& Tron, V. (2015). Model synthesis of nonlinear nonstationary dynamical systems in concentrating production using Volterra kernel transformation. Metallurgical and Mining Industry, 7(10), 6-9.

27. Morkun, V., Morkun, N., \& Tron, V. (2015). Distributed control of ore beneficiation interrelated processes under parametric uncertainty. Metallurgical and Mining Industry, 7(8), 18-21.

28. Morkun, V., \& Morkun, N. (2018). Estimation of the crushed ore particles density in the pulp flow based on the dynamic effects of high-energy ultrasound. Archives of Acoustics, 43(1), 61-67.

29. Morkun, V., Morkun, N., \& Pikilnyak, A. (2015). The study of volume ultrasonic waves propagation in the gas-containing iron ore pulp. Ultrasonics, (56), 340-343. https://doi.org/10.1016/j.ultras.2014.08.022

30. Morkun, V., Morkun, N., \& Pikilnyak, A. (2014) Ultrasonic phased array parameters determination for the gas bubble size distribution control formation in the iron ore flotation. Metallurgical and Mining Industry, (3), 28-31.

31. Pivnyak, G., Bondarenko, V., Kovalevs'ka, I., \& Illiashov, M. (2012). Geomechanical Processes During Underground Mining, 238 p. Book. https://doi.org/10.1201/b13157

32. Khomenko, O., Kononenko, M., \& Myronova, I. (2017). Ecological and technological aspects of iron-ore underground mining. Mining of Mineral Deposits, 11(2), 59-67. https://doi.org/10.15407/mining11.02.059 
33. Morkun, V. \& Tron, V. 2014. Ecological and economic optimization of iron ore processing automated control. Metallurgical and Mining Industry, 6(5), 8-10.

34. Khomenko, O.Ye. (2012). Implementation of energy method in study of zonal disintegration of rocks. Naukovyi Visnyk Natsionalnoho Hirnychoho Universytetu, (4), 44-54.

35. Andreev, B.M., Brovko, D.V., \& Khvorost, V.V. (2015). Determination of reliability and justification of object parameters on the surface of mines taking into account change-over to the lighter enclosing structures. Metallurgical and mining industry, (12), 378-382.

36. Babets, D.V., Sdvyzhkova, O.O., Larionov, M.H., Tereshchuk, R.M. (2017). Otsinka stiikosti masyvu hirskykh porid, shcho bazuietsia na ymovirnisnomu pidkhodi ta reitynhovykh klasyfikatsiiakh. Naukovyi visnyk NHU, (2), 58-64.

37. Khomenko, O., Kononenko, M., Kovalenko, I., \& Astafiev D. (2018). Self-regulating roof-bolting with the rock pressure energy use. E3S Web of Conferences, (60), 00009. https://doi.org/10.1051/e3sconf/20186000009

38. Khalymendyk, I., \& Baryshnikov, A. (2018). The mechanism of roadway deformation in conditions of laminated rocks. Journal of Sustainable Mining, 17(2), 41-47. https://doi.org/10.1016/j.jsm.2018.03.004

39. Malanchuk, Z.R., Moshynskyi, V.S., Korniienko, V.Y., Malanchuk, Y.Z., \& Lozynskyi, V.H. (2019). Obgruntuvannia parametriv rozmyvu y peretikannia pulpy tseolit-smektytovoho tufu u vydobuvnii kameri. Naukovyi visnyk NHU, (6), 11-18.

40. Stupnik, N., \& Kalinichenko, V. (2012). Parameters of shear zone and methods of their conditions control at underground mining of steep-dipping iron ore deposits in Kryvyi Rig basin. Geomechanical Processes During Underground Mining - Proceedings of the School of Underground Mining, 15-17. https://doi.org/10.1201/b13157-4

41. Petlovanyi, M., Kuzmenko, O., Lozynskyi, V., Popovych, V., Sai, K., \& Saik, P. (2019). Review of man-made mineral formations accumulation and prospects of their developing in mining industrial regions in Ukraine. Mining of Mineral Deposits, 13(1), 24-38. https://doi.org/10.33271/mining13.01.024

42. Bondarenko, V., Cherniak, V., Cawood, F., \& Chervatiuk, V. (2017). Technological safety of sustainable development of coal enterprises. Mining of Mineral Deposits, 11(2), 1-11. https://doi.org/10.15407/mining11.02.001

43. Stupnik, M., Kolosov, V., Kalinichenko, V., \& Pismennyi, S. (2014). Physical modeling of waste inclusions stability during mining of complex structured deposits. Progressive Technologies of Coal, Coalbed Methane, and Ores Mining, 25-30. https://doi.org/10.1201/b17547

44. Khomenko, O., Kononenko, M., \& Petlyovanyy, M. (2014). Investigation of stress-strain state of rock massif around the secondary chambers. Progressive Technologies of Coal, Coalbed Methane, and Ores Mining, 241-245. https://doi.org/10.1201/b17547-43

45. Khomenko, O., Kononenko, M., \& Petlovanyi, M. (2015). Analytical modeling of the back-fill massif deformations around the chamber with mining depth increase. New Developments in Mining Engineering 2015: Theoretical and Practical Solutions of Mineral Resources Mining, 265-269 https://doi.org/10.1201/b19901-47

46. Dreus, A.Yu., Sudakov, A.K., Kozhevnikov, A.A., Vakhalin, Yu.N. (2016). Study on thermal strength reduction of rock formation in the diamond core drilling process using pulse flushing mode. Naukovyi Visnyk Natsionalnoho Hirnychoho Universytetu, (3), 5-10.

47. Tron, V., Tsokurenko, O., Paraniuk, D., \& Haponenko, I. (2019). Formation of the adaptive fuzzy model of the rock geological structure for exploratory drilling. E3S Web of Conferences, (123), 01037. https://doi.org/10.1051/e3sconf/201912301037

48. Stupnik, M., Kolosov, V., Kalinichenko, V., \& Pismennyi, S. (2014). Physical modeling of waste inclusions stability during mining of complex structured deposits. Progressive Technologies of Coal, Coalbed Methane, and Ores Mining, 25-30. https://doi.org/10.1201/b17547

49. Pysmennyi, S., Brovko, D., Shwager,N., Kasatkina, I., Paraniuk, D., \& Serdiuk, O. (2018). Development of complexstructure ore deposits by means of chamber systems under conditions of the Kryvyi Rih iron ore field. Eastern-European Journal of Enterprise Technologies, 5(1(95)), 33 45. https://doi.org/10.15587/1729-4061.2018.142483 
50. Pysmenniy, S., Shvager, N., Shepel, O., Kovbyk, K., \& Dolgikh, O. (2020). Development of resource-saving technology when mining ore bodies by blocks under rock pressure. E3S Web of Conferences, (166), 02006. https://doi.org/10.1051/e3sconf/202016602006

51. Kalinichenko, O., Fedko, M., Kushnerov, I., \& Hryshchenko, M. (2019). Muck drawing by inclined two-dimensional flow. E3S Web of Conferences, (123), 01015 https://doi.org/10.1051/e3sconf/201912301015

52. Stupnik, N.I., Kalinichenko, V.A., Fedko, M.B., \& Mirchenko, Ye.G. (2013). Prospects of application of TNT-free explosives in ore deposites developed by uderground mining. Naukovyi Visnyk Natsionalnoho Hirnychoho Universytetu, (1), 44-48.

53. Stupnik, M., \& Kalinichenko, V. (2013). Magnetite quartzite mining is the future of Kryvyi Rig iron ore basin. Annual Scientific-Technical Collection - Mining of Mineral Deposits 2013, 49-52. https://doi.org/10.1201/b16354-10

54. Stupnik, N.I., Kalinichenko, V.A., Fedko, M.B., \& Mirchenko, Ye.G. (2013). Influence of rock massif stress-strain state on uranium ore breaking technology. Naukovyi Visnyk Natsionalnoho Hirnychoho Universytetu, (2), 11-16.

55. Ghodrati, B., \& Kumar, U. (2005). Reliability and operating environment-based spare parts estimation approach. Journal of Quality in Maintenance Engineering, 11(2), 169-184. https://doi.org/10.1108/13552510510601366

56. Wimmer, M., Nordqvist, A., Righetti, E., \& Petropoulos, N. (2015). Analysis of rock fragmentation and its effect on gravity flow at the Kiruna sublevel caving mine. In 11th International Symposium on Rock Fragmentation by Blasting (pp. 775-791). Carlton VIC, Australia: Australasian Institute of Mining and Metallurgy.

57. Herbert, R., \& Nordström, A. (2017). Leachate generation and nitrogen release from small-scale rock dumps at the Kiruna iron ore mine. In International Mine Water Association Conference 2017 (pp. 140-146). Lappeenranta, Finland.

58. Stupnik, M., Kalinichenko, V, Pysmennyi S., Kalinichenko, O. \& Fedko, M. (2016). Method of simulating rock mass stability in laboratory conditions using equivalent materials. Mining of Mineral Deposits, 10(3), 46-51. https://doi.org/10.15407/mining10.03.046

59. Stupnik, N.I., Fedko, M.B., \& Pismennyi, S.V. (2014). Development of recommendations for choosing excavation support types and junctions for uranium mines of state-owned enterprise skhidhzk. Naukovyi Visnyk Natsionalnoho Hirnychoho Universytetu, (5), 21-25

60. Stupnik, M., Kalinichenko, O., Kalinichenko, V., Pysmennyi, S. \& Morhun, O. (2018). Choice and substantiation of stable crown shapes in deep-level iron ore mining. Mining of Mineral Deposits, 12(4), 56-62. https://doi.org/10.15407/mining12.04.056

61. Khomenko, O., Kononenko, M., \& Petlovanyi, M. (2015). Analytical modeling of the back-fill massif deformations around the chamber with mining depth increase. New Developments in Mining Engineering 2015: Theoretical and Practical Solutions of Mineral Resources Mining, 265-269. https://doi.org/10.1201/b19901-47

62. Khomenko, O., Kononenko, M., \& Bilegsaikhan, J. (2018). Classification of Theories about Rock $\begin{array}{llll}\text { Pressure. Solid } & \text { State } & \text { Phenomena, } & \text { (277), }\end{array}$ https://doi.org/10.4028/www.scientific.net/ssp.277.157

63. Vladyko, O., Kononenko, M., \& Khomenko, O. (2012). Imitating modeling stability of mine workings. Geomechanical Processes During Underground Mining - Proceedings of the School of Underground Mining, 147-150. https://doi.org/10.1201/b13157-26

64. Carusone, O., \& Hudyma, M. (2017). Variations in apparent stress and energy index as indicators of stress and yielding around excavations. Proceedings of the First International Conference on Underground Mining Technology, 205-218. https://doi.org/10.36487/acg_rep/1710_16 carusone

65. Galaev, N.Z. (1990). Upravlenie sostoyaniem massiva gornykh porod pri podzemnoy razrabotke rudnykh mestorozhdeniy. Moskva: Nedra, 176.

66. Kalinichenko, V.O., Dolgikh, O.V., \& Dolgikh, L.V. (2019). Digital survey in studying open pit wall deformations. E3S Web of Conferences, (123), 01047. https://doi.org/10.1051/e3sconf $\underline{201912301047}$ 
67. Malakhov, G.M. (1990). Upravlenie gornym davleniem pri razrabotke rudnykh mestorozhdeniy Krivorozhskogo basseyna. Kyiv: Naukova dumka, 204.

68. Turchaninov, I.A., Iofis, M.A., \& Kaspar'yan, E.V. (1977). Osnovy mekhaniki gornykh porod. Moskva: Nedra, 503.

69. Hudyma, M. R., Potvin, Y., Grant, D. R., Milne, D., Brummer, R. K., Board, M. (1994). Geomechanics of Sill Pillar Mining. In 1st North American Rock Mechanics Symposium (pp. 969976). Austin, USA: University of Texas at Austin. 